\title{
Response of Muskmelon (Cucumis melo L.) cv. Durgapur Madhu to Different Levels of Gibberellic Acid and Time of Seed Soaking on Yield Parameters and Economics
}

\author{
K.S. Pandya ${ }^{*}$, L.R. Varma, T. Thomson, J.B. Thakar and Y.D. Pawar \\ Horticulture Instructional Farm, College of Horticulture SD Agricultural University, \\ Sardarkrushinagar 385506 Gujarat, India \\ *Corresponding author
}

\section{A B S T R A C T}

The present investigation entitled, "Response of muskmelon (Cucumis melo L.) cv. Durgapur Madhu to different levels of gibberellic acid and time of seed

Keywords

Muskmelon, GA3, Yield, Yield parameters and Economics.

Article Info

Accepted:

26 May 2017

Available Online:

10 June 2017 soaking on yield yield parameters and economics," was carried out from February to May 2013 in the summer season at Horticulture Instructional Farm, College of Horticulture, Sardarkrushinagar Dantiwada Agricultural University, Sardarkrushinagar. Experiment was laid out in randomized block design with factorial concept having four replications. There were five levels of $\mathrm{GA}_{3}(0 \mathrm{ppm}$, $250 \mathrm{ppm} .500 \mathrm{ppm}, 750 \mathrm{pm}$ and $1000 \mathrm{ppm}$ ) with two soaking periods 16 and 24 hours. There was treatment combinations altogether ten. The results revealed that maximum fruit set per cent, maximum number of fruit per plant, maximum yield of fruit per plant was recorded with treatment $\mathrm{GA}_{3}$ at $750 \mathrm{ppm}$, whereas in case of time of seed soaking maximum fruit set per cent, minimum days taken for first harvest, maximum average weight of fruit was recorded with $S_{1}$ treatments. Over all treatment combination $\mathrm{G}_{3} \mathrm{~S}_{2}\left(\mathrm{GA}_{3} 750 \mathrm{ppm}, 24\right.$ hours seed soaking) found to be beneficial.

\section{Introduction}

Muskmelon is an annual climbing or creeping herb with large, soft, hairy leaves and elliptical fruits of varying size and colour. It is an important vegetable crop cultivated throughout India particularly in the hot and dry North Western part of the country. Muskmelon fetches premium price in the market compared to other vegetables and is a popular vegetable grown under both rainfed and irrigated conditions almost throughout the year. It has great importance due to its short duration and high production potential as well as high nutritive value. It contains $78.0 \%$ edible portion, $95.2 \mathrm{~g}$ moisture, $0.3 \mathrm{~g}$ protein, $0.2 \mathrm{~g}$ fat, $0.4 \mathrm{~g}$ fiber, $0.11 \mathrm{mg}$ riboflavin, $0.4 \mathrm{~g}$ minerals, $32 \mathrm{mg}$ calcium, $26 \mathrm{mg}$ vitamin $\mathrm{C}$, $3.5 \mathrm{~g}$ carbohydrate per $100 \mathrm{~g}$ of fresh edible portion (Chaudhary, 2000).

In India area under muskmelon are about 41 (000) hectare with the production of 868 (000) MT (Anon. 2013). It is widely grown in Bihar, Uttar pradesh, Punjab, Rajasthan, Gujarat and some parts of Maharashtra 
(Chaudhary, 2000). It is grown on small scale but it has great prospects for large scale cultivation in the Gujarat state due to congenial soil and climatic conditions.

\section{Materials and Methods}

The investigation was conducted at Horticulture Instructional Farm, College of Horticulture, S. D. Agricultural University, Sardarkrushinagar during the year 2013. The experiment was laid out in four replications with Randomized Block Design with Factorial Concept. Five levels of gibberellic acid $\mathrm{G}_{0}\left(0 \mathrm{ppm} \mathrm{GA}_{3}\right.$, soaking of seeds in distilled water), $\mathrm{G}_{1}\left(250\right.$ ppm $\left.\mathrm{GA}_{3}\right), \mathrm{G}_{2}$ (500 ppm $\left.\mathrm{GA}_{3}\right), \mathrm{G}_{3}\left(750\right.$ ppm $\left.\mathrm{GA}_{3}\right)$ and $\mathrm{G}_{4}(1000$ ppm $\mathrm{GA}_{3}$ ) and two levels of seed soaking viz. 16 hours $\left(S_{1}\right)$ and 24 hours $\left(S_{2}\right)$ were taken singly and with combined form and thus total number of treatment combinations were altogether ten.

To raise the crop recommended package of practices was followed. The crop was sown on $21^{\text {st }}$ February, 2013. The effect of different treatments was studied on three randomly selected plants. The mean values were subjected to statistical analysis following analysis of variance technique (Panse and Sukhatme, 1995).

\section{Results and Discussion}

Maximum per cent fruit set was recorded with treatment $\mathrm{G}_{3}$, whereas in case time of seed soaking maximum per cent fruit set was recorded with treatment $S_{2}$. These findings are closely in accordance with Gopalkrishnan and Choudhury (1978) in watermelon, Biradar (2008) in bitter gourd and Mollier (2010) in cucumber.

Table.1 Response of musk melon (Cucumis melo L.) cv. Durgapur Madhu to different levels of gibberellic acid and time of seed soaking on yield parameters

\begin{tabular}{|c|c|c|c|c|}
\hline $\mathbf{G A}_{3}$ & \% Fruit set & $\begin{array}{l}\text { Days taken for } \\
\text { first harvest }\end{array}$ & $\begin{array}{l}\text { Average fruit } \\
\text { weight (g) }\end{array}$ & $\begin{array}{l}\text { No. of fruits / } \\
\text { plant }\end{array}$ \\
\hline \multicolumn{5}{|l|}{ G } \\
\hline $\mathbf{G}_{0}$ & 51.77 & 77.73 & 566.05 & 4.25 \\
\hline $\mathbf{G}_{1}$ & 56.85 & 76.47 & 695.43 & 5.31 \\
\hline $\mathbf{G}_{2}$ & 58.46 & 76.21 & 717.72 & 6.83 \\
\hline $\mathbf{G}_{\mathbf{3}}$ & 62.18 & 75.25 & 701.55 & 7.46 \\
\hline $\mathbf{G}_{4}$ & 59.03 & 75.93 & 732.16 & 6.51 \\
\hline S.Em \pm & 1.23 & 0.56 & 24.83 & 0.35 \\
\hline CD@ $@ 5 \%$ & 3.58 & NS & 72.07 & 1.01 \\
\hline \multicolumn{5}{|l|}{$\mathbf{S}$} \\
\hline $\mathbf{S}_{1}$ & 56.34 & 77.18 & 654.40 & 5.95 \\
\hline $\mathbf{S}_{2}$ & 58.98 & 75.46 & 710.77 & 6.20 \\
\hline S.Em \pm & 0.78 & 0.35 & 15.71 & 0.22 \\
\hline CD@ $@ 5 \%$ & 2.26 & 1.02 & 45.58 & NS \\
\hline \multicolumn{5}{|l|}{ GX S } \\
\hline S.Em \pm & 1.74 & 0.79 & 35.12 & 0.49 \\
\hline CD@ $95 \%$ & 5.06 & 2.28 & 101.92 & 1.43 \\
\hline CV\% & 6.04 & 2.06 & 10.29 & 16.22 \\
\hline
\end{tabular}


Table.2 Response of musk melon (Cucumis melo L.) cv. Durgapur Madhu to different levels of gibberellic acid and time of seed soaking on yield and benefit cost ratio

\begin{tabular}{|c|c|c|}
\hline $\mathbf{G A}_{3}$ & Yield /Plant (kg) & Yield /ha (q) \\
\hline \multicolumn{3}{|l|}{$\mathbf{G}$} \\
\hline $\mathbf{G}_{\mathbf{0}}$ & 2.68 & 89.33 \\
\hline $\mathbf{G}_{1}$ & 3.91 & 130.45 \\
\hline $\mathbf{G}_{2}$ & 4.80 & 160.18 \\
\hline $\mathbf{G}_{3}$ & 5.31 & 177.14 \\
\hline $\mathbf{G}_{4}$ & 4.55 & 151.88 \\
\hline S.Em \pm & 0.87 & 10.02 \\
\hline CD@ $5 \%$ & 0.30 & 29.04 \\
\hline \multicolumn{3}{|l|}{$\mathbf{S}$} \\
\hline $\mathbf{S}_{1}$ & 4.08 & 136.03 \\
\hline $\mathbf{S}_{2}$ & 4.42 & 147.56 \\
\hline S.Em \pm & 0.19 & 6.34 \\
\hline CD@ $5 \%$ & NS & NS \\
\hline \multicolumn{3}{|l|}{ GX S } \\
\hline S.Em \pm & 0.42 & 14.17 \\
\hline CD@ $5 \%$ & 1.23 & 41.18 \\
\hline CV\% & 19.98 & 19.98 \\
\hline
\end{tabular}

Table.3 Response of musk melon (Cucumis melo L.) cv. Durgapur Madhu to different levels of gibberellic acid and time of seed soaking on economics

\begin{tabular}{|l|c|c|c|c|c|}
\hline $\begin{array}{l}\text { Treat. } \\
\text { No. }\end{array}$ & $\begin{array}{c}\text { Cost of } \\
\text { cultivation } \\
\boldsymbol{\Sigma} / \text { /ha }\end{array}$ & $\begin{array}{c}\text { Yield (q) per } \\
\text { hectare }\end{array}$ & $\begin{array}{c}\text { Gross income } \\
\text { ₹/ha }\end{array}$ & $\begin{array}{c}\text { Net } \\
\text { income₹/ha }\end{array}$ & $\begin{array}{c}\text { Cost Benefit } \\
\text { Ratio }\end{array}$ \\
\hline $\mathrm{G}_{0} \mathrm{~S}_{1}$ & 67418.46 & 69.09 & 138180 & 70761.54 & $1: 1.04$ \\
\hline $\mathrm{G}_{0} \mathrm{~S}_{2}$ & 67418.46 & 109.56 & 219120 & 151701.54 & $1: 2.25$ \\
\hline $\mathrm{G}_{1} \mathrm{~S}_{1}$ & 69370.46 & 112.30 & 224600 & 155229.54 & $1: 2.23$ \\
\hline $\mathrm{G}_{1} \mathrm{~S}_{2}$ & 69370.46 & 148.60 & 297200 & 227829.54 & $1: 3.28$ \\
\hline $\mathrm{G}_{2} \mathrm{~S}_{1}$ & 71322.46 & 149.56 & 299120 & 227797.54 & $1: 3.19$ \\
\hline $\mathrm{G}_{2} \mathrm{~S}_{2}$ & 71322.46 & 170.79 & 341580 & 270257.54 & $1: 3.78$ \\
\hline $\mathrm{G}_{3} \mathrm{~S}_{1}$ & 73274.46 & 175.71 & 351420 & 278145.54 & $1: 3.79$ \\
\hline $\mathrm{G}_{3} \mathrm{~S}_{2}$ & 73274.46 & 178.58 & 357160 & 283885.54 & $\mathbf{1 : 3 . 8 7}$ \\
\hline $\mathrm{G}_{4} \mathrm{~S}_{1}$ & 75226.46 & 173.48 & 346960 & 271733.54 & $1: 3.61$ \\
\hline $\mathrm{G}_{4} \mathrm{~S}_{2}$ & 75226.46 & 130.27 & 260540 & 185313.54 & $1: 2.46$ \\
\hline
\end{tabular}

Days taken for first harvest was influenced by time of seed soaking and minimum days required for first harvest was recorded with treatment $S_{2}$. Similar result was observed by Ram et al., (2003) in muskmelon.

Maximum number of fruit per plant was recorded with treatment $\mathrm{G}_{3}$. Similar result was found with by Ram et al., (2001 and 2003) in muskmelon. Maximum number of fruit per plant may be due to more number of hermaphrodite flower and better vegetative growth (Biradar et al., 2008). Maximum average weight of fruit was recorded with treatment $\mathrm{G}_{2}$ whereas in case of time of seed 
soaking, maximum average weight of fruit was recorded with treatment $S_{2}$. These findings are closely in accordance with the findings of Ram et al., (2001, 2003) in muskmelon and Hidayatullah et al., (2011) in cucumber (Table 1). Maximum yield of fruit per plant was recorded with treatment $\mathrm{G}_{3}$ whereas in case of time of seed soaking, maximum yield of fruit per plant was recorded with treatment $S_{2}$. These findings are closely in accordance with the findings of Ram et al., (2001 and 2003) in muskmelon, Hidayatullah et al., (2011) in cucumber, Deepthi (2008) in muskmelon and Biradar (2008) in bitter gourd.

Yield of fruit per ha (q) was significantly influenced by different levels of $\mathrm{GA}_{3}$. Maximum fruit yield per ha (q) was recorded with treatment $\mathrm{G}_{3}$. These findings are closely in accordance with the findings of Deepthi, (2008) in muskmelon and Biradar (2008) in bitter gourd and Mollier (2010) in cucumber (Table 2).

The results summarized in table 3 indicated that maximum net income Rs. 2, 83, $885.54 \mathrm{ha}^{-1}$ and highest net CBR (1:3.87) was obtained with $\mathrm{G}_{3} \mathrm{~S}_{2}$ (750 ppm $\mathrm{GA}_{3}, 24$ hour seed soaking). The minimum net income Rs. 70,761.54 $\mathrm{ha}^{-1}$ and lowest net CBR (1: 1.04) was obtained with $\mathrm{G}_{0} \mathrm{~S}_{1}$ (0 ppm GA 3,16 hour seed soaking).

From the investigation it can be concluded that different levels of $\mathrm{GA}_{3}$ and time of seed soaking was significantly influenced yield and economics of muskmelon. The treatment $\mathrm{G}_{3}\left(750 \mathrm{ppm} \mathrm{GA}_{3}\right)$ and treatment combination $\mathrm{G}_{3} \mathrm{~S}_{2}\left(750 \mathrm{ppm} \mathrm{GA}_{3}\right.$, 24 hours seed soaking) found to be beneficial.

\section{References}

Anonymous (2013). NHB Database- 2013. Ministry of Agriculture, Government of India

Biradar, G. and Navalagatti C. M. (2008). Effect of plant growth regulators on physiology and quality in bitter gourd (Momordica charantia L.). M.Sc thesis submitted to the University of Agricultural Sciences, Dharwad.

Chaudhary, B. (2000). Vegetable production, National Book trust pub. New Delhi, 150151.

Deepthi, H.R. (2008).Physiology and quality of muskmelon (Cucumis melo L.) as influenced by plant growth regulators. $M$. Sc thesis submitted to the University of Agricultural sciences, Dharwad.

Gopalkrishnan, P. K and Choudhury, B. 1978. Effect of plant regulator sprays on modification of sex, fruit set and development in watermelon. Indian $J$. Hort., 35: 235-241.

Hidayatullah, Bano, A., Khokhar, K. M. and Mahmood, T. (2011). Effect of seed soaking treatment with growth regulators on phytohormone level and sex modification in cucumber (Cucumis sativus L.). Afri. J. Pl. Sci.5 (10): 599-608.

Mollier. (2010). Influence of plant growth regulators on growth, physiology and yield in cucumber. M.sc thesis submitted to the University of Agricultural sciences, Dharwad.

Panse, V. G. and Sukhatme, P. V. (1995).Statistical methods for agricultural workers, ICAR. Pub., New Delhi.

Ram Asrey, Singh, G. N., Shukla, H. S. and Rajbir Singh. (2001). Effect of seed soaking with gibberellic acid on growth and fruiting of muskmelon (Cucumis melo L.). Haryana J. Horti. Sci., 3(3/4): 277-278.

Ram Asrey., Singh, G. N. and Shukla, H. S. (2003).Effect of seed soaking with gibberellic acid on growth and fruiting of muskmelon (Cucumis melo L.). Haryana J. Horti. Sci., 32 (3/4): 297-298.

\section{How to cite this article:}

Pandya, K.S., L.R. Varma, T. Thomson, J.B. Thakar and Pawar, Y.D. 2017. Response of Muskmelon (Cucumis melo L.) cv. Durgapur Madhu to Different Levels of Gibberellic Acid and Time of Seed Soaking on Yield Parameters and Economics. Int.J.Curr.Microbiol.App.Sci. 6(6): 2352-2355. doi: https://doi.org/10.20546/ijcmas.2017.606.278 